\title{
Land Sensitivity Analysis of Degradation using MEDALUS model: Case Study of Deliblato Sands, Serbia
}

\author{
Ratko Kadović1* ${ }^{*}$, Yousef Ali Mansour Bohajar ${ }^{1}$, Veljko Perović2, \\ Snežana Belanović Simić ${ }^{1}$, Mirjana Todosijević ${ }^{1}$, Sonja Tošić ${ }^{3}$, Milosav Anđelić ${ }^{4}$, \\ Dragan Mlađan ${ }^{5}$, Una Dovezenski ${ }^{1}$ \\ ${ }^{1}$ University of Belgrade, Serbia \\ Faculty of Forestry \\ ${ }^{2}$ Institute of Soil Science, Serbia \\ ${ }^{3}$ Institute for Nature Conservation of Serbia \\ ${ }^{4}$ Ministry of Agriculture and Rural Development of Montenegro \\ ${ }^{5}$ The Academy of Criminalistic and Police Studies \\ *Corresponding author's e-mail: ratko.kadovic@sfb.bg.ac.rs
}

Keywords: Deliblato sands, land degradation, sensitivity, MEDALUS, GIS mapping.

\begin{abstract}
This paper studies the assessment of sensitivity to land degradation of Deliblato sands (the northern part of Serbia), as a special nature reserve. Sandy soils of Deliblato sands are highly sensitive to degradation (given their fragility), while the system of land use is regulated according to the law, consisting of three zones under protection. Based on the MEDALUS approach and the characteristics of the study area, four main factors were considered for evaluation: soil, climate, vegetation and management. Several indicators affecting the quality of each factor were identified. Each indicator was quantified according to its quality and given a weighting of between 1.0 and 2.0. ArcGIS 9 was utilized to analyze and prepare the layers of quality maps, using the geometric mean to integrate the individual indicator map. In turn, the geometric mean of all four quality indices was used to generate sensitivity of land degradation status map. Results showed that $56.26 \%$ of the area is classified as critical; $43.18 \%$ as fragile; $0.55 \%$ as potentially affected and $0.01 \%$ as not affected by degradation. The values of vegetation quality index, expressed as coverage, diversity of vegetation functions and management policy during the protection regime are clearly represented through correlation coefficient $(0.87$ and 0.47$)$.
\end{abstract}

\section{Introduction}

Land degradation represents a global process which ultimately leads to a reduction of soil fertility. Over large areas of the world soils are exposed to the loss of biological production and resilience caused by both natural and anthropogenic factors (Contador et al. 2009). In dry areas, land degradation coupled with extreme bio-physical and socio-economic phenomena may turn into an irreversible process of environmental degradation - desertification (Montanarella 2007). The term of desertification was generally associated with geo-physical conditions (e.g. soil, slope, vegetation cover) coupled with drought features and water availability. As maintained by UNCCD (2008), combating drought, land degradation and desertification represent an international priority. It is important to identify and describe the driving forces leading to land degradation in order to properly understand the phenomenon at a local scale.

Several models have been adopted and many studies undertaken for assessing and mapping desertification or land degradation risk. This has led to a large number of local models that specialize in developing and applying models in other areas (Geeson et al. 2002), although all indices should be reinvestigated and adjusted to fit local conditions. Among numerous models, MEDALUS model (MEditerranean Desertification And Land USe), developed by the European Commission is of great significance (Brandt and Thornes 1996). MEDALUS model is widely used in the European countries as a successful tool for the detection of most endangered areas in terms of land degradation (Salvati and Zitti 2009, Contador et al. 2009, Santini et al. 2010, Vieira et al. 2015). This model has been largely tested in the Mediterranean basin countries and has shown good results (Kosmas et al. 1999, Geeson et al. 2002, Basso et al. 2012). The application of MEDALUS model in GIS environment is also one of the reasons for its widespread use. The complexity of the ecosystem makes it hard to carry out management decisions. The use of advance technologies, primarily GIS, through the form of thematic content, enables the interaction of the system for land resources management. Moreover, it ensures accuracy and speed of assessing and mapping (Kosmas et al. 1999, Geeson et al. 2002).

Deliblato sands is the biggest European continental desert and represents the oldest desert in Europe ("European 
Sahara"). Deliblato sands is an isolated complex of sandy masses located in the northern part of Serbia and southern part of Banat, situated between the River Danube and the western slopes of Carpathians (Drakulić 1969). An environmentally sensitive area to degradation (ESA) could be considered as a spatially delimited area in which some key aspects related to its sustainability are unbalanced and unsustainable for a particular environment.

Based on the available data on soil, climate, vegetation and management system, the main goal of this work is to indicate the sensitivity and fragility of Deliblato sands to degradation processes, using MEDALUS model. It is essential to call for specific decision tools and identify the right areas for certain decision and/or measures. Furthermore, it is very important to carry out a reliable database on the sensitivity to degradation/desertification using GIS which enables spatial data analysis that can be presented in a graphic and/or cartographic form.

\section{Materials and methods}

\section{Study area}

The study area of Deliblato sands as an isolated complex of sandy masses, has an elliptical shape and is oriented southeast - northwest, spreading between coordinates: $44^{\circ} 46^{\prime}-45^{\circ} 2^{\prime} \mathrm{N}$ and $20^{\circ} 55^{\prime}-21^{\circ} 18^{\prime}$ E (Fig. 1). Deliblato sands is around $35 \mathrm{~km}$ long and around $11 \mathrm{~km}$ wide, i.e., it covers an area of approximately $340 \mathrm{~km}^{2}$. Specificity of Deliblato sands is its dune relief, where the difference between the dune tops and inter-dune hollows reaches $30 \mathrm{~m}$, as well as the lack of surface watercourses. At the most northwestern part, dunes and inter-dune hollows take milder forms. The altitude of Deliblato sands ranges from $70 \mathrm{~m}$ asl to $194 \mathrm{~m}$ asl (the highest peak is Pluc) at the farthest northwest. The main sandy masses are located in the heart of fertile agricultural areas (Drakulić 1969). The coordinates of each sampling point were taken using a GPS with a precision of 1-3 meters (Fig. 1).

The climate of Deliblato sands is generally semi-arid with specific microclimate, characterized by early and late frosts and significant temperature fluctuations, ranging from -25 to $+45^{\circ} \mathrm{C}$. During winter, wind košava blows, reaching the speed of $174 \mathrm{~km} \mathrm{~h}^{-1}$ (Zarić 2014). This stormy wind belongs to a group of dangerous hydrometeorological phenomena, especially when the wind speed is higher than $17.2 \mathrm{~m} \mathrm{~s}^{-1}$ or when it occurs in a form of leeches or tornados that are typical of southeastern Banat (Kadović et al. 2014).

Opinions on time and origin of Deliblato sands are different. According to Rakić (1980/81), aeolian sands are very homogenic in lithological sense, although research has shown that there are two parts: dense varieties prevail in a 60-m deep layer, while in the upper part which is 15 $\mathrm{m}$ deep lies typical vejač - even nowadays redeposited by košava wind.

In pedological sense, Deliblato sands represent a relatively young soil formation, in terms of its degree of evolution. Geological age does not have to match the pedological age which means that sand, in its origin, can be a significantly older formation. From the pedological point of view, there are no signs indicating Pleistocene, let alone Pliocene age of sand (Antić et al. 1969).

When it comes to vegetation Stjepanović-Veseličić (1953) singled out four types: sandy, steppe-like, swamp-like and forest type of vegetation. There are associations among specific types, with a certain number of sub-associations. The afforestation of Deliblato sands began in 1818 and is characterized by several periods. As stated in the forest management plan for 2007-2017, forests cover 16,998 ha of Deliblato sands.

According to the Law on Deliblato sands (1976), this area has been given a status of Special Nature Reserve highlighting its primary function - the protection from wind erosion. By regulation for protection (2002), Special Nature Reserve was declared as the last and biggest oasis of sandy, steppe-like, forest and swamp vegetation in the Pannonian Basin and as an area of remarkable and universal value for the protection of nature and science, and it is divided into three zones of protection (Fig. 2). It is classified as a category IV of International Union for Conservation of Nature (IUCN) classification - Habitat



Fig. 1. Study area 
and Species Management Area. In addition, Deliblato sands is: Important Birds Area (IBA), Important Plant Area in Europe (IPA), Emerald Area, Ramsar Area (Labudovo okno, a part of the desert alongside the Danube) and potential UNESCO world heritage site.

\section{The MEDALUS method}

The MEDALUS method (Kosmas et al. 1999) identifies regions that are environmentally sensitive areas by index of sensitivity (ESAs), obtained from the geometric average of four indices resulting from the environment and human action. These indices relate to the following: soil quality index (SQI), climate quality index (CQI), vegetation cover quality index (VQI) and the management system quality and human influence index (MQI). The first three quality indices provide insight into the environmental conditions, while the last one expresses an assessment of the pressure resulting from the anthropogenic activities. Each of these indices is grouped into different uniform class with a weighting factor assigned to each class; then four layers are evaluated. After determining indices for each layer, the ESAs to desertification are defined by combining four quality layers. All data defining the four main layers are introduced in GIS and overlaid in accordance with the developed algorithm which takes the geometric mean to compile maps of ESAs to desertification. Certain maps are obtained using the Inverse Distance Weighting (IDW) deterministic interpolation techniques. IDW function generates the interpolated surface by assigning values to unknown points from a weighted sum of values of known points (Shepard 1968).

The scores assigned to different parameters range from 1 (the best value) to 2 (the worst value). The land degradation sensitivity index of Deliblato sands $\left(\mathrm{ESA}_{\mathrm{DS}}\right)$ is given by the following equation:

$$
\mathrm{ESA}_{\mathrm{DS}}=(\mathrm{SQI} \cdot \mathrm{CQI} \cdot \mathrm{VQI} \cdot \mathrm{MQI})^{1 / 4}
$$

The model implicitly assumes that each of the four indices taken individually has only limited capacity to affect the final value of the ESA index and only when several parameters have a high score, can an area be assigned to a high sensitivity class. This hypothesis is in agreement with what is currently known and implies that no environmental condition on its own can exclude or determine the possibility of the risk of desertification (Giordano et al. 2007).

The MEDALUS model allows for a change in the number of parameters to be used for assessing the quality indices. We used three parameters for the soil, three for the vegetation, three for the climate and two for the management quality on the basis of the available data for the entire Deliblato sands area.

\section{Soil Quality}

Field and laboratory research of soil has been conducted on samples from 31 pedological profiles. According to WRB (IUSS Working Group WRB 2015), soils were categorized into four groups: I - Protic Arenosol (Calcaric), II - Arenosol (Haplic, Calcaric), III - Chernozem (Arenic), IV - Gleysol (Calcaric, Arenic).

Soil quality indicators for mapping the sensitivity of Deliblato sands were specifically selected from the aspect of (a) available moisture and (b) erosion tolerance. In this case, soil quality for the $0-10 \mathrm{~cm}$ layer was estimated based on the following parameters: soil texture, humus content and content of $\mathrm{CaCO}_{3}$. Soils with calcium carbonate content $>5 \%$ (Klik 2008) are more erodible. It is assumed that bedrock, depth of sand, drainage, etc. are uniform and do not call for separate analysis in terms of defining and categorizing them into classes in regard to the degree of protection from degradation/ desertification.

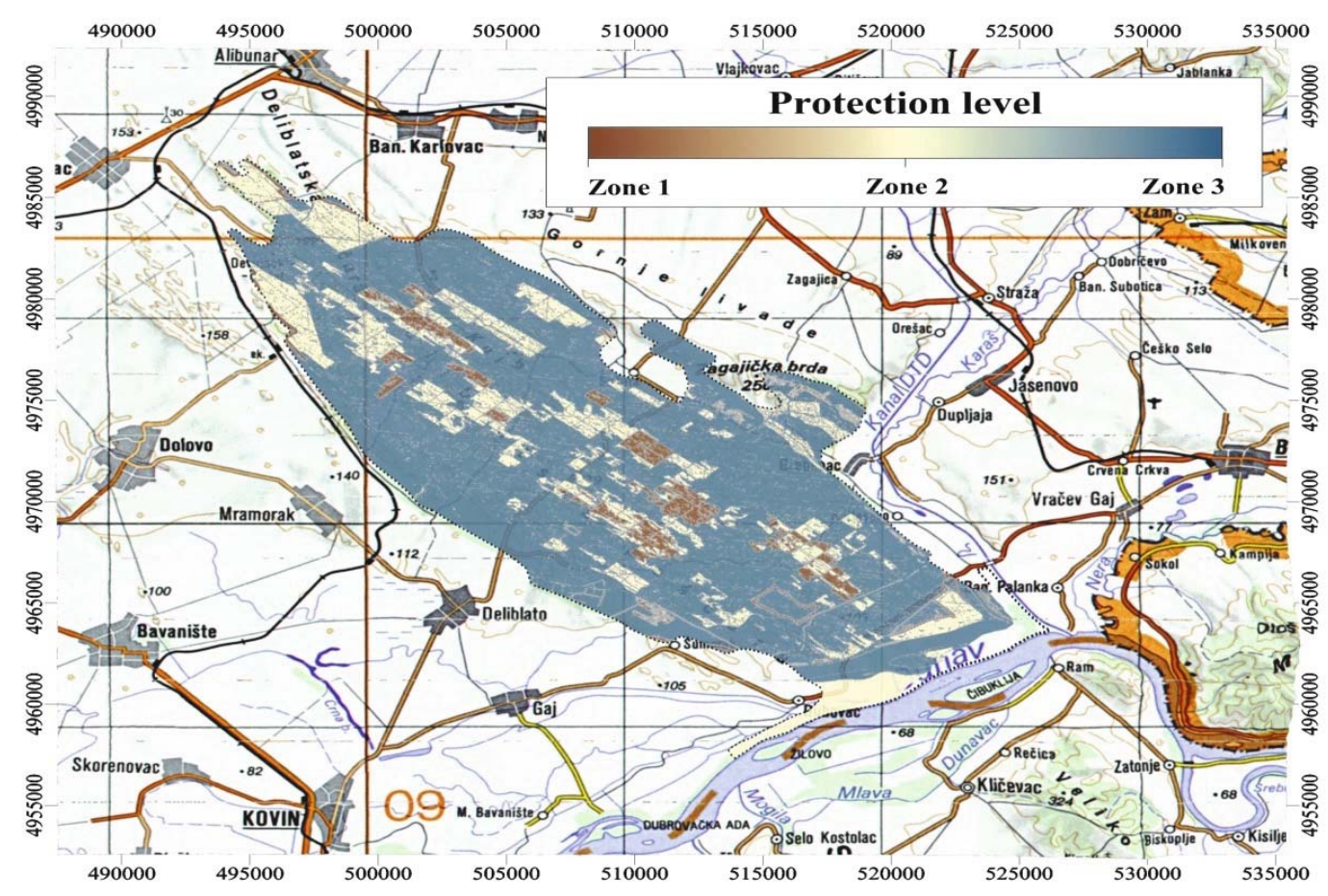

Fig. 2. Legal protection zones of land use system of Deliblato sands 
Classes and assigned weighting indices for selected parameters for soil quality assessment are given in Table 1, according to Kosmas et al. (1999), Basso et al. (2012), Sepehr et al. (2007), Entezari et al. (2013).

Soil quality index (SQI), which in this case represents index of soil erodibility, is calculated as the product of the aforementioned attributes - texture, humus content and content of $\mathrm{CaCO}_{3}$, using the algorithm:

$$
\begin{gathered}
\text { SQI }(\text { Soil Quality Index })= \\
=\left(\text { Texture } \cdot \text { Humus Content } \cdot \mathrm{CaCO}_{3} \text { Content }\right)^{1 / 3}
\end{gathered}
$$

\section{Climate Quality}

Characteristics of climate for a wider area of Deliblato sands have been studied for three main weather stations: Banatski Karlovac, Vršac and Bela Crkva, as well as for pluviometer station Padina, for the period of 1981-2010. Based on the precipitation regime, air temperatures and potential evapotranspiration (for GMS), values of aridity index (AI) have been calculated (UNEP 1992) for different periods: year, growing period, JJA months and individually for months (June, July and August). The aridity index proposed by UNEP is also used by FAO. In July and August especially, there were 20-22 of 30 and 9-21 of 30 years respectively, with arid and semiarid AI values. In addition to aridity index, values of standardized precipitation index (SPI) have been analyzed: SPI-1, SPI-2, SPI-3 and SPI-6. Based on complex analyses, SPI-1 has been selected for July for the period of 1981-2010. Probability of drought in the area of Deliblato sands SPI-1 during July for the period of 1981-2010 is given in Table 2, while every third year there are moderate, severe or extreme droughts.

Wind regime in Deliblato sands is of great importance, where the typical southeastern wind košava is especially significant. It is a strong gusty wind with gusts of at least of $11 \mathrm{~m} \mathrm{~s}^{-1}$ and average speed of $5-10 \mathrm{~m} \mathrm{~s}^{-1}$, though it can gain speed higher than $30 \mathrm{~m} \mathrm{~s}^{-1}$ (Zarić 2014). Kadović et al. (2014) state the probability of blustery wind occurrence $\left(>17.2 \mathrm{~m} \mathrm{~s}^{-1}\right)$ in a wider area of Deliblato sands, while Zarić (2014) reports the maximal wind gusts of $48 \mathrm{~m} \mathrm{~s}^{-1}$ (Janury 11th, 1987) and of $47 \mathrm{~m} \mathrm{~s}^{-1}$ (February 24th, 1988 and February 1st, 2014).

Based on the results of a study carried out in Hungary (Mezõsi et. al 2013), limit value of wind speed for the occurrence of wind erosion on sandy soils is $6.0 \mathrm{~m} \mathrm{~s}^{-1}$, whereas the speed of $12.0 \mathrm{~m} \mathrm{~s}^{-1}$ signifies a high probability for the appearance of wind erosion.

Classes and assigned weighting indices for selected parameters for climate quality assessment are shown in Table 3, according to Sepehr et al. (2007) and Vieira et al. (2015) for AI, McKey et al. (1993) for droughts, and Mezõsi et al. (2013), Zarić (2014) and Kadović et al. (2014) for wind speed.

Climate quality index (CQI), which in this case represents index of erosivity, is calculated as the product of the aforementioned attributes - aridity index, SPI-1 (July) and wind speed, using the algorithm:

\begin{tabular}{|c|c|c|c|c|}
\hline Factor & Class & Description & Characteristic & Index \\
\hline \multirow{3}{*}{ Soil Texture Class } & 1 & Sandy Loam (SL) & Good & 1 \\
\hline & 2 & Loamy sand (LS) & Moderate & 1.2 \\
\hline & 3 & Sand (S) & Very poor & 2 \\
\hline \multirow{3}{*}{$\begin{array}{l}\text { Organic Matter, \% } \\
\text { (Humus Content) }\end{array}$} & 1 & $>3.0$ & Very good & 1 \\
\hline & 2 & $1.0-3.0$ & Moderate & 1.5 \\
\hline & 3 & $<1.0$ & Very poor & 2 \\
\hline \multirow{3}{*}{$\mathrm{CaCO}_{3}$ Content, \% } & 1 & $<2.5$ & Good & 1 \\
\hline & 2 & $2.5-5.0$ & Moderate & 1.5 \\
\hline & 3 & $>5.0$ & Poor & 2 \\
\hline
\end{tabular}

Table 1. Classes and assigned weightings for assessing soil quality index

\begin{tabular}{|c|c|c|c|c|c|c|c|c|c|}
\hline \multirow[b]{3}{*}{ SPI-1 } & \multirow[b]{3}{*}{ Category } & \multicolumn{8}{|c|}{ Weather station } \\
\hline & & \multicolumn{2}{|c|}{ Banatski Karlovac } & \multicolumn{2}{|c|}{ Vršac } & \multicolumn{2}{|c|}{ Bela Crkva } & \multicolumn{2}{|c|}{ Padina } \\
\hline & & $\begin{array}{c}\text { No. of } \\
\text { droughts } \\
\text { in } 30 \text { yrs. }\end{array}$ & $\begin{array}{l}\text { Drought } \\
\text { frequency }\end{array}$ & $\begin{array}{c}\text { No. of } \\
\text { droughts } \\
\text { in } 30 \text { yrs. }\end{array}$ & $\begin{array}{l}\text { Drought } \\
\text { frequency }\end{array}$ & $\begin{array}{c}\text { No. of } \\
\text { droughts } \\
\text { in } 30 \text { yrs. }\end{array}$ & $\begin{array}{l}\text { Drought } \\
\text { frequency }\end{array}$ & $\begin{array}{c}\text { No. of } \\
\text { droughts } \\
\text { in } 30 \text { yrs. }\end{array}$ & $\begin{array}{l}\text { Drought } \\
\text { frequency }\end{array}$ \\
\hline-1 to -1.49 & $\begin{array}{l}\text { Moderate } \\
\text { drought }\end{array}$ & 4 & $\begin{array}{c}\text { More than } \\
1 \text { in } 10 \\
\text { yrs. }\end{array}$ & 3 & $\begin{array}{c}1 \text { in } 10 \\
\text { yrs. }\end{array}$ & 6 & $\begin{array}{c}2 \text { in } 10 \\
\text { yrs. }\end{array}$ & 4 & $\begin{array}{c}\text { More than } \\
1 \text { in } 10 \\
\text { yrs. }\end{array}$ \\
\hline-1.5 to 1.99 & $\begin{array}{l}\text { Severe } \\
\text { drought }\end{array}$ & 5 & $\begin{array}{c}\text { More than } \\
1 \text { in } 20 \\
\text { yrs. }\end{array}$ & 3 & $\begin{array}{c}\text { More than } \\
1 \text { in } 20 \\
\text { yrs. }\end{array}$ & 3 & $\begin{array}{c}2 \text { in } 20 \\
\text { yrs. }\end{array}$ & 1 & $\begin{array}{c}1 \text { in } 20 \\
\text { yrs. }\end{array}$ \\
\hline$<-2$ & $\begin{array}{l}\text { Extreme } \\
\text { drought }\end{array}$ & 1 & $\begin{array}{c}1 \text { in } 30 \\
\text { yrs. }\end{array}$ & 1 & $\begin{array}{c}1 \text { in } 30 \\
\text { yrs. }\end{array}$ & 3 & $\begin{array}{c}3 \text { in } 30 \\
y r s .\end{array}$ & 5 & $\begin{array}{c}5 \text { in } 30 \\
\text { yrs. }\end{array}$ \\
\hline
\end{tabular}

Table 2. Probability of drought occurrence in Deliblato sands for SPI-1 (July), 1981-2010 
CQI (Climate Quality Index) =

$=(\text { Aridity } \cdot \text { SPI- } 1 \cdot \text { Wind Speed })^{1 / 3}$

\section{Vegetation Quality}

The quality of vegetation was analyzed from the aspects of (a) the type of vegetation cover and vegetation coverage, (b) protection of soil from erosion and (c) drought tolerance. Index of soil coverage was obtained from the analysis of NDVI.

Normalized difference vegetation index (NDVI) is often used for monitoring vegetation dynamics with exit values ranging from -1.0 to 1.0 . Negative values close to -1 correspond to infertile areas. Values close to 0 usually correspond to water and irrigated soils. Low positive values represent shrubs, meadows and pastures, while high positive values indicate forest vegetation.

The map of weighting relations of vegetation role in the protection from erosion is based on CORINE 2006. For the area of Deliblato sands, the existing CORINE 2006 layer has been reclassified into the following dominant groups of vegetation: group I - steppe grass vegetation, group II - moist meadows, group III - shrubs and group IV - natural oak and linden forests and forest vegetation. There are three classes from the aspect of vegetation cover and four classes from the aspect of erosion protection and drought tolerance.

Classes and weighting indices of vegetation coverage, expressed in percentages, are given in Table 4 (Kosmas et al. 1999, Sepehr et al. 2007, Basso et al. 2012, Salvati et al. 2013).
Vegetation quality index (VQI) is calculated as the product of the aforementioned attributes - vegetation coverage, soil protection from erosion and vegetation tolerance to drought, using the following algorithm:

$$
\begin{gathered}
\text { VQI }(\text { Vegetation Quality Index })= \\
=(\text { Erosion protection } \cdot \text { Drought resistance } \\
\cdot{\text { Vegetation Coverage })^{1 / 3}}^{\text {. }}
\end{gathered}
$$

\section{Management Quality}

From the aspect of utilization, the area of Deliblato sands is divided into several main forms, all of which are significant in terms of quality management and the level of anthropogenic effect to stress production. This paper examines only the aspects of the intensity of forest use: forest deciduous and conifer cultures, natural forests of oak, linden and poplar, moist meadows and steppe vegetation.

The intensity of forest use (forest cultures and natural forests) was determined by the assessment of actual (A) and sustainable utilization (A/S). The intensity was categorized into three classes, starting from the relation A/S. Data on available utilization policies have been gathered and estimated for each level of implementation, referring to protection regime as Special Nature Reserve, depending on the level at which they are executed. Table 5 shows the classes and assigned weighting indices for selected parameters for management quality assessment, according to Kosmas et al. (1999), Basso et al. (2012) and Salvati et al. (2013).

Table 3. Classes and assigned weightings for assessing climate quality index

\begin{tabular}{|c|c|c|c|c|}
\hline Factor & Class & Description & Characteristic & Index \\
\hline \multirow{3}{*}{ Aridity Index (AI) } & 1 & $>0.65$ & Low & 1 \\
\cline { 2 - 5 } & 2 & $0.51-0.65$ & Moderate & 1.5 \\
\cline { 2 - 5 } & 3 & $<0.50$ & High & 2 \\
\hline \multirow{3}{*}{ SPI-1 } & 1 & -1.0 to -1.49 & Low & 1 \\
\cline { 2 - 5 } & 2 & -1.50 to -1.99 & Moderate & 1.5 \\
\cline { 2 - 5 } & 3 & $<-2.0$ & High & 2 \\
\hline \multirow{3}{*}{ Wind Speed, $\mathrm{m} \mathrm{s}^{-1}$} & 1 & $<6.0$ & Low & 1 \\
\cline { 2 - 5 } & 2 & $6.0-12.0$ & Moderate & 2 \\
\cline { 2 - 5 } & 3 & $>17.2$ & High & 2 \\
\hline
\end{tabular}

Table 4. Classes and assigned weightings for assessing vegetation quality index

\begin{tabular}{|c|c|c|c|c|}
\hline Factor & Class & Description & Characteristic & Index \\
\hline \multirow{3}{*}{ Vegetation coverage (\%) } & 1 & High & $>40$ & 1 \\
\cline { 2 - 5 } & 2 & Low & $10-40$ & 1.8 \\
\cline { 2 - 5 } & 3 & Very low & Conifer forest plantings & 1 \\
\hline \multirow{4}{*}{ Erosion protection } & 1 & Very high & Natural deciduous forests and plantings & 1.2 \\
\cline { 2 - 5 } & 2 & High & Steppe vegetation and shrubs & 1.6 \\
\cline { 2 - 5 } & 3 & Moderate & Annual agricultural crops & 2 \\
\cline { 2 - 5 } & 4 & Low & Conifer forest plantings & 1 \\
\hline \multirow{4}{*}{ Drought resistance } & 1 & Very high & Natural deciduous forests and plantings & 1.2 \\
\cline { 2 - 5 } & 2 & High & Steppe vegetation and shrubs & 1.4 \\
\cline { 2 - 5 } & 3 & Moderate & Annual agricultural crops & 2 \\
\cline { 2 - 5 } & 4 & Very low & &
\end{tabular}


Index of management quality (MQI) is calculated as the product of the aforementioned attributes - intensity of vegetation use and soil use policies, using the following algorithm:

MQI (Management Quality Index) = $=(\text { Intensity of land use } \cdot \text { Protection policies })^{1 / 2}$

Type of soil sensitivity to degradation/desertification of Deliblato sands is defined as the final step in environment quality assessment (soil quality, climate quality and vegetation quality) and management quality.

\section{Statistical analyses}

Statistical analysis for soil indicators was performed using the STATGRAPHICS Centurion version XVI, MultipleSample Comparisen. ANOVA test was performed for analyses of significant differences between percent content of sand particles $(2-0.02 \mathrm{~mm})$, silt particles $(0.02-0.002 \mathrm{~mm})$, clay
$(<0.002 \mathrm{~mm})$, organic matter content (humus) and $\mathrm{CaCO}_{3}$, for texture classes (sand, loamy sand and sandy loam).

The correlation between raster data sets represents correlation coefficients between them that actually are the relationship of dependence between analyzed layers. Research analyzed mutual correlation between factors (SQI, CQI, VQI and MQI) and their individual correlation with $\mathrm{ESA}_{\mathrm{DS}}$, by calculating previously obtained results in raster form. Positive numbers mean a positive correlation that exists between the two variables, and the correlation between the two variables is strongest when the value is close to 1 . We used the Band Collection Statistics tool in ArcGIS.

\section{Results}

\section{Soil quality index}

The results of statistical analysis of chosen indicators for soil quality are presented in Table 6.

$\mathrm{F}_{0.05}=3.32$ (critical value of $\mathrm{F}$ for the 0.05 significance level)

Table 5. Classes and assigned weightings for assessing management quality index

\begin{tabular}{|c|c|c|c|c|}
\hline Factor & Class & Description & Characteristic & Index \\
\hline \multirow{3}{*}{$\begin{array}{c}\text { Intensity of vegetation } \\
\text { use }\end{array}$} & 1 & Low & $\mathrm{A} / \mathrm{S}=0$ & 1 \\
\hline & 2 & Moderate & $\mathrm{A} / \mathrm{S}<1$ & 1.2 \\
\hline & 3 & High & $\mathrm{A} / \mathrm{S}=1$ or greater & 2 \\
\hline \multirow{3}{*}{ Soil use policies } & 1 & High & Complete: $>75 \%$ of area under protection & 1 \\
\hline & 2 & Moderate & Partially: $25-75 \%$ of area under protection & 1.5 \\
\hline & 3 & Low & Incomplete: $<25 \%$ of area under protection & 2 \\
\hline
\end{tabular}

Table 6. Summary statistics for soil indicators

\begin{tabular}{|c|c|c|c|c|c|}
\hline \multirow[b]{2}{*}{ Soil properties } & \multirow{2}{*}{$\begin{array}{l}\text { F-Ratio } \\
\text { Df }(2 / 28)\end{array}$} & \multirow[b]{2}{*}{ P-Value } & \multicolumn{3}{|c|}{ Soil texture classes } \\
\hline & & & $\begin{array}{c}\text { Sand }(n=13) \\
(a)\end{array}$ & $\begin{array}{l}\text { Loamy sand }(\mathrm{n}=11) \\
(\mathbf{b})\end{array}$ & $\begin{array}{c}\text { Sandy loam }(n=7) \\
\text { (c) }\end{array}$ \\
\hline $\begin{array}{l}\text { Sand, \% } \\
(2.0-0.02 \mathrm{~mm}) \\
- \text { Average } \\
-S D \\
-\operatorname{CV}(\%)\end{array}$ & 29.80 & 0.0000 & $\begin{array}{c}93.23(\mathrm{a}) \\
2.01 \\
2.15\end{array}$ & $\begin{array}{c}88.26(\mathbf{b}) \\
2.29 \\
2.59\end{array}$ & $\begin{array}{c}83.31(\mathbf{c}) \\
4.42 \\
5.30\end{array}$ \\
\hline $\begin{array}{l}\text { Silt, \% } \\
(0.02-0.002 \mathrm{~mm}) \\
\text { - Average } \\
- \text { SD } \\
-\mathrm{CV}(\%)\end{array}$ & 6.64 & 0.0044 & $\begin{array}{c}4.65(a) \\
1.98 \\
42.63\end{array}$ & $\begin{array}{c}7.54(\mathbf{b}) \\
2.08 \\
27.59\end{array}$ & $\begin{array}{c}8.14(\mathbf{b}) \\
3.35 \\
41.17\end{array}$ \\
\hline $\begin{array}{l}\text { Clay, \% } \\
(<0.002 \mathrm{~mm}) \\
- \text { Average } \\
-\mathrm{SD} \\
-\mathrm{CV}(\%)\end{array}$ & 18.34 & 0.0000 & $\begin{array}{c}2.12(a) \\
0.42 \\
20.0\end{array}$ & $\begin{array}{c}4.21(\mathbf{b}) \\
0.92 \\
21.97\end{array}$ & $\begin{array}{c}5.48(\mathbf{c}) \\
2.34 \\
42.74\end{array}$ \\
\hline $\begin{array}{l}\text { Organic matter, \% } \\
\text { - Average } \\
\text { - SD } \\
\text { - CV (\%) }\end{array}$ & 10.25 & 0.0005 & $\begin{array}{c}2.33(\mathbf{a}) \\
0.96 \\
41.02\end{array}$ & $\begin{array}{c}4.59(\mathbf{b}) \\
1.66 \\
36.10\end{array}$ & $\begin{array}{c}4.78(\mathbf{b}) \\
1.71 \\
35.59\end{array}$ \\
\hline $\begin{aligned} & \mathrm{CaCO}_{3}, \% \\
- & \text { Average } \\
- & \mathrm{SD} \\
- & \mathrm{CV}(\%)\end{aligned}$ & 4.00 & 0.0297 & $\begin{array}{c}6.21(a) \\
2.81 \\
45.32\end{array}$ & $\begin{array}{c}3.77(a) \\
2.47 \\
65.50\end{array}$ & $\begin{array}{c}3.38(\mathbf{b}) \\
2.00 \\
59.17\end{array}$ \\
\hline
\end{tabular}


As the calculated value $\mathrm{F}$ is larger than the value given in Table 6 in all cases $\left(\mathrm{F}_{2.28}=3.32\right.$ for $\left.\alpha=0.05\right)$, it is evident that there are significant differences between texture classes in terms of all indicators. Since the P-value of the F-test is less than 0.05 , there is a statistically significant difference between the analyzed indicators at $95.0 \%$ confidence level. Statistically significant differences between homogenous groups (LSD test) are identified using words (a), (b) and (c).

Depending on their value, each of the three quality indices is classified as high, moderate or low, apart from the climate quality index which is classified into two quality indices moderate and low. Finally, all four are combined together to calculate a single index of desertification/land degradation, using the equation (1).

Synthesis map of soil quality index (SQI), from the aspect of erosion of sandy soils, was obtained using the equation (2) and by reclassification of values gained from the analysis of data of selected indicators. The map of soil quality index (SQI) is shown in Figure 2, according to classes.

According to the map (Fig. 3), almost $5.05 \%$ of the study area (1705.35 ha) was located in the high quality class (range $<1.13), 82.85 \%$ was located in the moderate quality (1.131.45 ) class (28016.01 ha) and $12.06 \%$ was located in the low quality ( $>1.46$ ) class (4076.46 ha) of degradation.

\section{Climate Quality Index}

Synthesis map of climate quality index (CQI), from the aspect of wind erosion, was obtained using the equation (3) and by

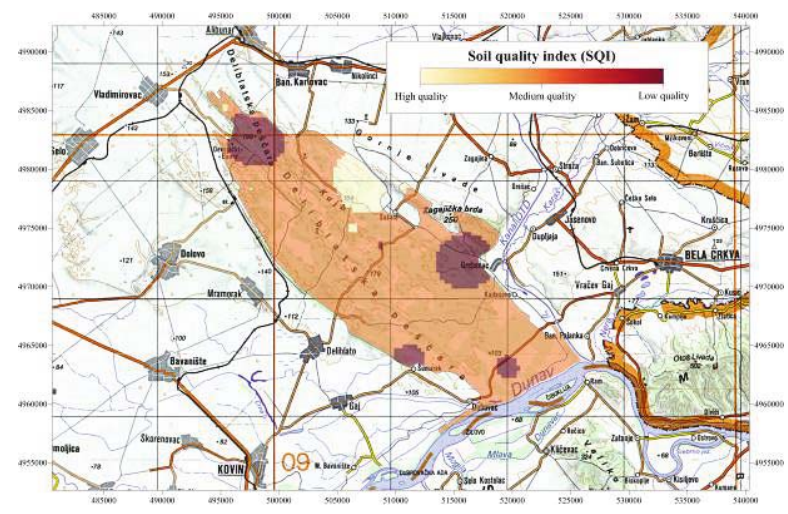

Fig. 3. Synthesis map of soil quality index for selected classes

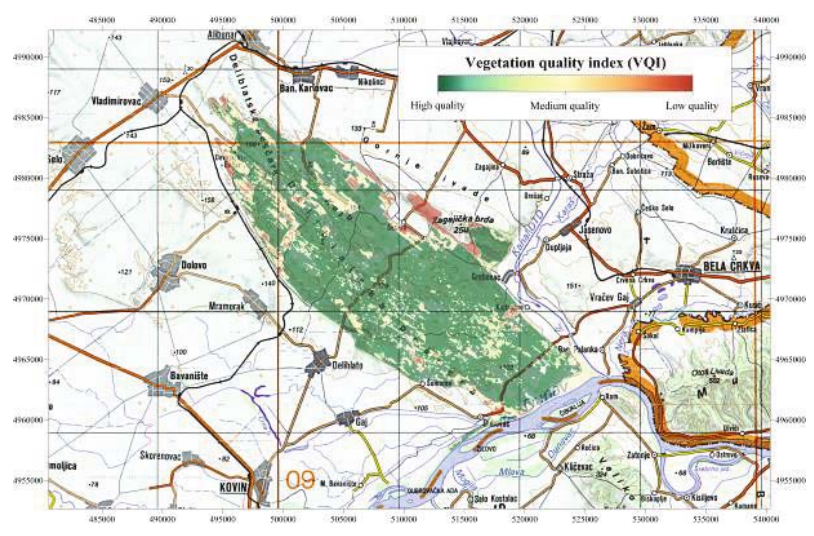

Fig. 5. Synthesis map of vegetation quality index for selected classes reclassification of values gained from the analysis of data of selected indicators. There are two separate classes of climate quality - medium and low. The map of climate quality index (CQI) is shown in Figure 4, according to classes.

According to the map (Fig. 4), there are two classes of climate quality: $46.24 \%$ of the study area (15626.92 ha) was located in the moderate quality class (range 1.15-1.81) and $53.76 \%$ was located in the low quality $(>1.81)$ class (18170.90 ha).

\section{Vegetation quality index}

Synthesis map of vegetation quality index (VQI) was obtained using the equation (4) and by reclassification of values gained from the analysis of data of selected indicators. The map of vegetation quality index (VQI) is shown in Figure 5, according to classes.

According to the map (Fig. 5), 78.46\% of study area (26519.41 ha) was located in the high quality class (range $1-1.6), 16.74 \%$ was located in the moderate quality (1.7-3.7) class (5658.87 ha) and almost $4.79 \%$ was located in the low quality (3.7-16) class (1619.54 ha) of vegetation.

\section{Management quality index}

Synthesis map of management quality index (MQI) was obtained using the equation (5) and by reclassification of values gained from the analysis of data of selected indicators. The map of management quality index (MQI) is shown in Figure 6, according to classes.

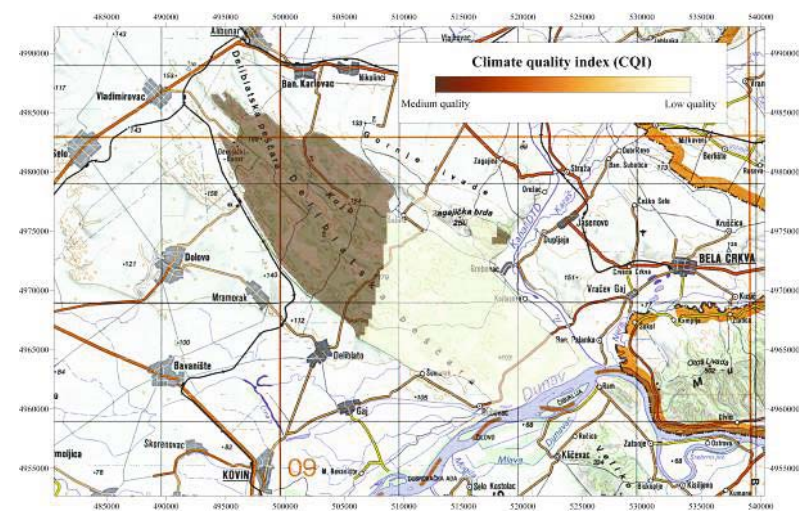

Fig. 4. Synthesis map of climate quality index for selected classes

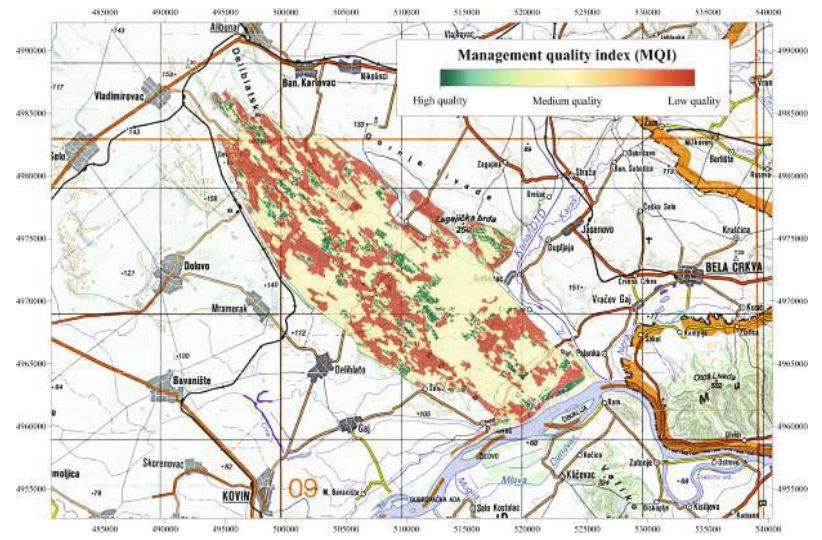

Fig. 6. Synthesis map of management quality index for selected classes 
According to the map (Fig. 6), 11.14\% of the study area (3766.10 ha) was located in the high quality class (range 1-1.25), 51.04\% was located in the moderate quality (1.26-1.50) class (17249.82 ha) and $37.82 \%$ was located in the low quality $(>1.51)$ class $(12781.90 \mathrm{ha})$ of management quality.

Type of land sensitivity to degradation/desertification of Deliblato sands is defined as the final step in environment quality assessment (soil quality, climate quality and vegetation quality) and management quality.

Synthesis map of sensitivity to degradation of Deliblato sands, shown in Figure 7, was obtained by reclassification of the values gained from prior analysis and using the aforementioned algorithm.

According to Kosmas et al. (1999), such index identifies four main classes of areas threatened with land degradation ("critical”, "fragile”, "potentially affected” and ,non-affected”) and are further differentiated (critical and fragile classes) into a three-point scale, ranging from 3 (high sensitivity) to 1 (lower sensitivity), risk as C3-critical, C2-critical, C1-critical, F3-fragile, F2-fragile, F1-fragile.

Classes of land sensitivity of Deliblato sands are given in Table 7, expressed both in hectares (ha) and percentages (\%), and Table 8 shows the results of raster correlation between factors.

\section{Discussion}

Conducted field, laboratory and model studies for the area of Deliblato sands, the analyses of so far conducted activities, management policy of the area and regulations are confirmed by the results presented in this work. The results obtained using MEDALUS model point to high land sensitivity of Deliblato sands to degradation processes.

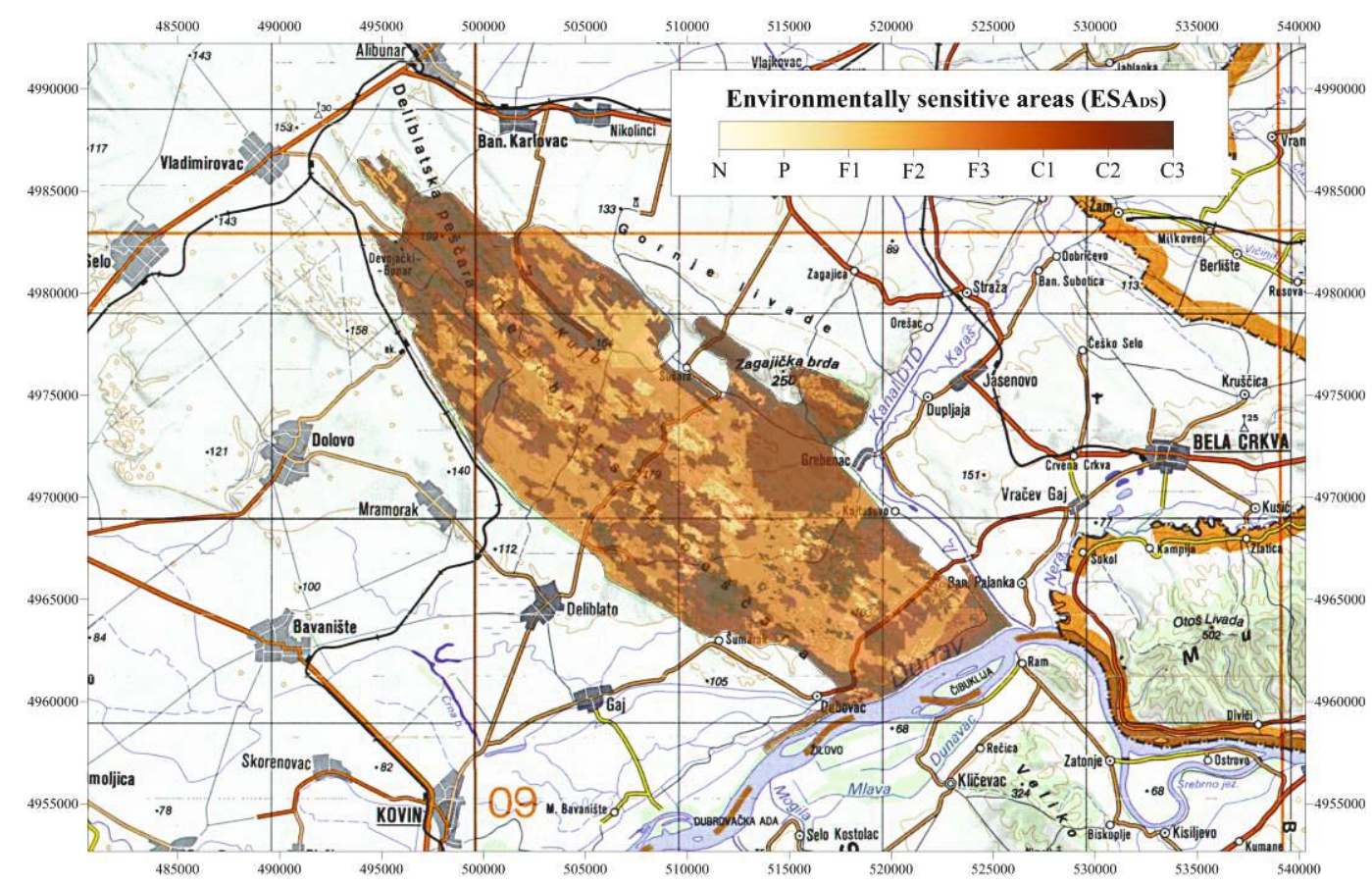

Fig. 7. Map of sensitivity of Deliblato sands according to classes

Table 7. Classes of land sensitivity to degradation of Deliblato sands

\begin{tabular}{|c|c|c|c|}
\hline \multirow{2}{*}{ Category } & \multicolumn{2}{|c|}{ Area } & \multirow{2}{*}{ Range } \\
\cline { 2 - 3 } & ha & $\%$ & $<1.17$ \\
\hline N & 3.39 & 0.01 & $1.17-1.22$ \\
\hline P & 186.15 & 0.55 & $1.23-1.26$ \\
\hline F1 & 843.69 & 2.50 & $1.27-1.32$ \\
\hline F2 & 2532.63 & 7.49 & $1.33-1.37$ \\
\hline F3 & 11217.39 & 33.19 & $1.38-1.41$ \\
\hline C1 & 648.18 & 1.92 & $1.42-1.53$ \\
\hline C2 & 9943.44 & 29.42 & $>1.53$ \\
\hline C3 & 8422.94 & 24.92 & \\
\hline Total & 33797.82 & 100.00 & \\
\hline
\end{tabular}


Table 8. Raster correlation between factors

\begin{tabular}{|c|c|c|c|c|c|}
\hline & ESADS & SQI & CQI & VQI & MQI \\
\hline ESADS & 1.00 & 0.22 & -0.02 & 0.87 & 0.47 \\
\hline SQI & 0.22 & 1.00 & 0.06 & -0.06 & 0.02 \\
\hline CQI & -0.02 & 0.06 & 1.00 & -0.01 & -0.07 \\
\hline VQI & 0.87 & -0.06 & -0.01 & 1.00 & 0.17 \\
\hline MQI & 0.47 & 0.02 & -0.07 & 0.17 & 1.00 \\
\hline
\end{tabular}

The final map of sensitivity (Fig. 7, Table 7) was obtained by partitioning the $\mathrm{ESA}_{\mathrm{DS}}$ index into four classes of sensitivity values, arranged according to their degree of sensitivity as: non-affected $-\mathrm{N}$; potentially affected $-\mathrm{P}$; fragile $-\mathrm{F}(\mathrm{F} 1, \mathrm{~F} 2$ and $\mathrm{F} 3)$ and critical $-\mathrm{C}(\mathrm{C} 1, \mathrm{C} 2$ and $\mathrm{C} 3)$ areas.

Very small area (3.9 ha or $0.01 \%)$ of Deliblato sands belongs to the class non-affected (very low sensitivity) - areas with very low values of critical factors, with good balance between natural and socioeconomic factors. Class potentially affected (low sensituvity) covers the area of 186.15 ha or $0.55 \%$ of Deliblato sands - areas under degradation processes on which combinations of utilization system or indirect factors may cause severe problems. Class fragile (medium sensitivity) is divided into three sub-classes: F1, F2 and F3. Whole class "fragile" covers 14593.71 ha or $\mathbf{4 3 . 1 8 \%}$ of DS. A change of any factor may disturb the balance between natural conditions and human action, probably leading to the intensification of degradation process. The expansion of such processes can have negative effects under all zones of protection: Zone 1 - $50.23 \%$, Zone $2-36.20 \%$, and $43.14 \%$ of Zone 3. Class critical (high sensitivity) is also divided into three sub-classes: C1, C2 and C3. Whole class ,critical“" covers 19014.56 ha or $\mathbf{5 6 . 2 6 \%}$ of DS - areas already highly degraded or exposed to severe threats of degradation. Protected areas of zones belong to: Zone $1-49.77 \%$, Zone $2-63.72 \%$ and Zone $3-54.83 \%$.

The results also confirm that MEDALUS model represents a useful tool for simulations that support sustainable management of land in areas sensitive to degradation processes, such as Deliblato sands. In accordance with the law, Deliblato sands area is divided into three zones of protection regime: zone 1 consists of areas that should be preserved as the most valuable ones from the aspect of nature conservation; zone 2 consists of areas that need special measures of advancement to be taken in order to preserve the original natural values; zone 3 is an area in which most activities based on the principles of sustainable development are performed with aim to increase all values of the protected natural resource - natural, cultural and aesthetic.

Following Kosmas et al. (1999), the first application of proposed methodology for different types of areas environmentally sensitive to desertification, performed for three characteristic Mediterranean areas are: the island of Lesvos in Greece (Kosmas et al. 1999), the Agri basin in Italy (Basso et al. 1999) and the Alentejo region in Portugal (Roxo et al. 1999). Eight classes of land sensitivity were identified according to the obtained ESI scores. Sensitivity scores provide a reliable estimation of different levels of sensitivity occurring in a specific area. In all three examples, the final map of sensitivity was obtained by partitioning the ESA index into four classes of sensitivity values, arranged according to their degree of sensitivity as: non-affected - N; potentially affected - P; fragile - F (F1, F2 and F3) and critical - C (C1, C2 and C3) areas.

Mapping sensitivity to land degradation in Extremadura, Spain (Contador et al. 2009), the final map of sensitivity was obtained by partitioning the ESA index into four classes of sensitivity values, arranged according to their degree of sensitivity as: non-affected, N; potentially affected, P; fragile, F and critical, C. Critical and fragile areas were further subdivided into three classes, depending on the degree of sensitivity: $\mathrm{C} 3, \mathrm{C} 2, \mathrm{C} 1$ and $\mathrm{F} 3, \mathrm{~F} 2, \mathrm{~F} 1$.

Using the standard and adjusted MEDALUS approaches for 1984 and 2008 over the Bustan 3 area in Egypt (Bakr et al. 2012), the final map of sensitivity was obtained partitioning the ESA index into four classes of sensitivity values, arranged according to their degree of sensitivity as: non-affected $-\mathrm{N}$; potentially affected $-\mathrm{P}$; fragile $-\mathrm{F}(\mathrm{F} 1, \mathrm{~F} 2$ and $\mathrm{F} 3)$ and critical $-\mathrm{C}(\mathrm{C} 1, \mathrm{C} 2$ and $\mathrm{C} 3)$ areas.

MEDALUS method enables the assessment of additional variables that characterize specific habitat conditions, depending on local conditions. The same procedure refers to the process of classification by interpreting different layers of information. In fact, classifications simplify data by summarizing the values of different attributes within a limited number of classes (Salvati and Zitti 2009). The interpretation of data calls for uniform classifications with data organized into reference systems or when different types of ecosystems are compared, in a simple and acceptable way (Salvati et al. 2013). In the case of Deliblato sands, the changes in index of vegetation quality due to the applied management policy during the protection regime and implementation of system within Special Nature Reserve are clearly expressed through correlation coefficient (0.87). Simulation technique, applied with available information and supported by collected data, can be used for the study of specific degradation processes, primarily wind erosion.

Climate variations, deterioration of soil conditions and alterations in soil use system need a continual monitoring that is becoming support to the strategy of sustainable management. The given results illustrate that monitoring of degradation/ desertification in the area of Deliblato sand is feasible, since that it is simple and flexible in the application of relevant cheap variables which are widely used beyond the specified area. However, in the assessment of available information, critical analysis is needed in order to apply the suitable system of classification, as the choice of intervals that would be assigned to classes of sensitivity mean the introduction of a significant level of subjective element that affects the final result of the assessment (Giordano et al. 2007). This method can also be applied when some information is missing or when some need 
to be added. This characteristic makes it highly applicable to other geographical areas, which has been represented in References.

\section{Conclusion}

MEDALUS is a spatially oriented model that can be easily modified on the basis of local conditions and data availability. The results obtained using MEDALUS model confirm that it represents a useful tool for simulations that support sustainable management in areas sensitive to degradation processes, such as Deliblato sands. According to the results, $99.44 \%$ of total area of Deliblato sands belongs to classes of medium and high sensitivity to degradation. The facts that $56.26 \%$ of area belongs to high sensitivity class and $43.18 \%$ to medium sensitivity class are of great importance. Furthermore, this system enables the consideration of additional variables which characterize specific habitat conditions, depending on local conditions.

The changes in index of vegetation quality due to the applied management policy during the protection regime and implementation of system within Special Nature Reserve are clearly expressed through correlation coefficient $(0.87)$. The results presented the intensity and severity of land degradation in this area and provided us with an overview of the evolution of ecosystem that can be used as an essential tool to help decision-making and planning, identifying priority areas for intervention in the fight against land degradation.

Finally, this work has presented a methodological application of MEDALUS model which enables the use of existing indices, but also the introduction of new ones. The presented methodology can be used for defining priorities and developing strategies in the local areas sensitive to land degradation processes, as well as wider areas of the Balkans.

\section{Acknowledgements}

This paper was realized as a part of the project "Studying Climate Change and its Influence on the Environment: Impacts, Adaptation and Mitigation" (III43007), financed by the Ministry of Education and Science of the Republic of Serbia, within the framework of integrated and interdisciplinary research for the period 2011-2014.

\section{References}

Antić, M., Avdalović, V. \& Jović, N. (1969). Evolution, genetic link and ecological value of certain types of sands in Deliblato sands, Deliblato sands I, Jugoslovenski poljoprivredno-šumarski centar i ŠIK Pančevo, pp. 47-66. (in Serbian)

Bakr, N., Weindorf, D.C., Bahnassy, H.M. \& El-Badawi, M.M. (2012). Multi-temporal assessment of land sensitivity to desertification in a fragile agro-ecosystem: Environmental indicators, Ecological Indicators, 15, pp. 271-280.

Basso, F., Bellotti, A., Faretta, S., Ferrara, A., Mancino, G., Pisante, M. \& Quaranta, G. (1999). The Agri basin (Italy), in: The Medalus Project: Mediterranean Desertification and Land Use. Manual on Key Indicators of Desertification and Mapping Environmentally Sensitive Areas to Desertification, Kosmas, C., Kirkby, M., Geeson, N. (Eds.). European Union 18882, 1999.

Basso, B., De Simone, L., Cammarano, D., Martin, E.C., Margiotta, S., Grace, P.R., Yeh, M.L. \& Chou, T.Y. (2012). Evaluating responses to land degradation mitigation measures in Southern Italy, International Journal of Environmental Research, 6, 2, pp. 367-380.

Brandt, J.C. \& Thornes, J.B. (1996). Mediterranean Desertification and Land Use, John Wiley \& Sons, London 1996.

Contador, J.F.L., Schnabel, S., Gutiérrez, A.G. \& Fernández, M.P. (2009). Mapping sensitivity to land degradation in Extremadura, SW Spain, Land Degradation and Development, 20, pp. 129-144.

Drakulić, J. (1969). Position and general conditions of the object, Deliblato sands 1818-1968, pp. 9-26, ŠIK, Pančevo. (in Serbian)

Entezari, M., Honarmandnezhad, S., Sadat, S. \& Nematolahi, F. (2013). Use of modified CORINE methodology for comparison, potential soil Erosion and actual soil erosion in the basin watershed - jahrom, Fars, Iran. Journal of Basic and Applied Scientific Research, 3, 3, pp. 183-188.

Geeson, N.A., Brandt, C.J. \& Thornes, J.B. (2002). Mediterranean desertification: a mosaic of processes and responses, Wiley 2002.

Giordano, L., Giordano, F., Grauso, S., Iannetta, M., Sciortino, M., Rossi, L. \& Bonati, G. (2007). Identification of areas sensitive to desertification in Sicily Region, (https://www.google.rs/search? $\mathrm{q}=$ Giordano + et + al. $+2007 \&$ ie $=$ utf- $8 \&$ oe $=$ utf $8 \&$ gws_rd $=$ cr\&ei $=1$ YyzVqbAPIWesgH84qioBA\#q=Desertification+in+Sicily+Regi on+Giordano+et+al.+2007(02.04.2016)).

Kadović, R., Spasov, P., Ali Bohajar, Y. M., Belanović Simić, S. \& Košanin, O. (2014). Analysis of aridity indicators in the Deliblato sands, Bulletin of the Faculty of Forestry, 109, pp. 97-112.

Kadović, R., Miljković, P., Perić, V., Živanović, N., Bohajar, Y.M.A. \& Belanović Simić, S. (2014). An analysis of erodible fraction of sandy soils in Deliblato Sands, Erozija, Udruženje bujičara Srbije, 40, pp. 38-52. (in Serbian)

Klik, A. (2008).Wind erosion assessment in Austria using wind erosion equation and GIS. BOKU - University of Natural Resources and Applied Life Sciences Vienna (http://citeseerx.ist. psu.edu/viewdoc/download?doi=10.1.1.124.9706\&rep=rep1\&ty $\mathrm{pe}=\operatorname{pdf}(02.04 .2016))$.

Kosmas, C., Ferrara, A., Briasouli, H. \& Imeson, A. (1999). Methodology for mapping Environmentally Sensitive Areas (ESAs) to Desertification, in: The Medalus project: Mediterranean desertification and land use. Manual on key indicators of desertification and mapping environmentally sensitive areas to desertification, Kosmas C., Kirkby M. \& Geeson, N. (Eds.). European Union 1999.

Kosmas, C., Gerontidis, St., Detsis, V., Zafiriou, Th. \& Marathianou, M. (1999). The island of Lesvos (Greece), in: The Medalus Project: Mediterranean Desertification and Land Use. Manual on Key Indicators of Desertification and Mapping Environmentally Sensitive Areas to Desertification, Kosmas, C., Kirkby, M. \& Geeson, N. (Eds.). European Union 18882, 1999.

McKee, T.B., Doesken, N.J. \& Kleist, J. (1993). The relation of drought frequency and duration to time scales, Proceedings, AMS Eighth Conference on Applied Climatology, 17-22 January 1993, Anaheim, CA, pp. 179-184.

Mezõsi, G., Blanka, V., Bata, T., Kovács, F. \& Meyer, B. (2013). Estimation of regional differences in wind erosion sensitivity in Hungary, Natural Hazards and Earth System Sciences, 1, pp. 4713-4750 (www.nat-hazards-earth-syst-sci-discuss. net/1/4713/2013/ (07.02.2016)).

Montanarella, L. (2007). Trends in land degradation in Europe, in: Climate and Land Degradation. Sivakumar, M.V. \& N'diangui, N. (Eds). Springer, Berlin, Germany, pp. 181-193.

Rakić, M. (1980/81). New data on structure of Deliblato sands. Vesnik (Geologija), Zavod za geološka i geofizička istraživanja, Beograd, serija A, 38/39, pp. 187-195. (in Serbian)

Roxo, M.J., Mourao, J.M., Rodrigues, L. \& Casimiro, P.C. (1999). The Alentejo region (Metrola municipality, Portugal), in: The Medalus Project: Mediterranean desertification and land 
use. Manual on key indicators of desertification and mapping environmentally sensitive areas to desertification, Kosmas, C., Kirkby, M. \& Geeson, N. (Eds.). European Union 18882, 1999.

Salvati, L. \& Zitti, M. (2009). Assessing the impact of ecological and economic factors on land degradation vulnerability through multi-way analysis, Ecological Indicators, 9, pp. 357- 363.

Salvati, L., Mancino, G., De Zuliani, E., Sateriano, A., Zitti, M. \& Ferrara, A. (2013). An expert system to evaluate environmental sensitivity: a local - scale approach o desertification risk, Applied ecology and environmental research, 11, 4, pp. 611-627. (http:// www.ecology.uni-corvinus.hu (07.02.2016)).

Santini, M., Caccamo, G., Laurenti, A., Noce, S. \& Valentini, R. (2010). A multi-component GIS framework for desertification risk assessment by an integrated index, Applied Geography, 30, pp. 394-415.

Sepehr, A., Hassanli, M., Ekhtesasi, R. \& Jamali, J.B. (2007). Quantitative assessment of desertification in south of Iran using MEDALUS method, Environmental monitoring and Assessment, 134, 1-3, pp. 243-254.

Shepard, D. (1968). A two-dimensional interpolation function for irregularly-spaced data, in: ACM 68: Proceedings of the 1968 23rd ACM national conference. ACM, New York, USA, pp. $517-524$
Stjepanović-Veseličić, L. (1953). The vegetation of Deliblato sands. Serbian Academy of Sciences and Arts - SASA, Special edition, book CCXVI, Institute for ecology and biogeography, book 4, Belgrade 1953. (in Serbian)

Vieira, R.M.S.P., Tomasella, J., Alvalá, R.C.S., Sestini, M.F., Affonso, A.G., Rodriguez, D.A., Barbosa, A.A., Cunha, A.P.M.A., Valles, G.F., Crepani, E., de Oliveira, S.B.P., de Souza, M.S.B., Calil, P.M., de Carvalho, M.A., Valeriano, D.M.F., Campello, C.B. \& Santana, M.O. (2015). Identifying areas susceptible to desertification in the Brazilian northeast, Solid Earth, 6, pp. 347-360 (www.solid-earth. net/6/347/2015/doi:10.5194/se-6-347-2015(09.09.2016)).

Zarić, M. (2014). Stormy and blustery gusts of košava - blizzard and snowstorm in north and northeast parts of Serbia. The analysis of synoptic situation and weather from January 26th to February 4th, 2014, Republic Hydrometeorological Service of Serbia - Belgrade. (in Serbian)

UNCCD (2008). Desertification Coping with Today's Global Challenges in the Context of the Strategy of the United Nations Convention to Combat Desertification, Unites Nations Convention to Combat Desertification, Report on the High-Level Policy Dialogue, Bonn, Germany 2008.

UNEP (1992). World atlas of desertification, Edward Arnold, London 1992. 